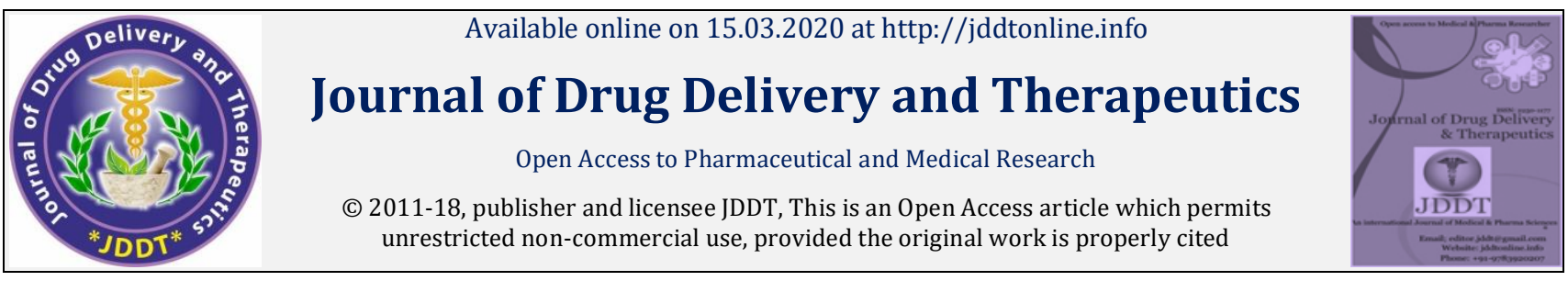

Open Access

Research Article

\title{
Changes in Life Quality of Chronic Kidney Disease Patients with Hemodialysis Who Are Given Vitamin B1, B6, and B12 Parenterally
}

\author{
Rizaldy Taslim Pinzon, Angela \\ Duta Wacana Christian University School of Medicine Yogyakarta Indonesia
}

\begin{abstract}
Background: Chronic kidney disease (CKD) is a disease that causes a progressive decrease in kidney function, which can end in kidney failure disease and will have an impact on decreasing quality of life. Previous research has shown that by giving vitamins B1, B6, and B12 can improve quality of life.

Aim: To measure changes in quality of life in patients with chronic kidney disease who were given vitamins B1, B6, and B12 parenterally. Material and Methods: This study used quasi experimental (one group pre and post test) in 117 patients who were selected in Bethesda Hospital and Panti Rapih Hospital Yogyakarta hemodialysis unit. Patients were given vitamins B Combination injections twice a week in each hemodialysis for 4 weeks. Quality of life was measured by SF-8 questionnaire on the first day of hemodialysis before given vitamins (pre-test) and on the 30th day, after eight injection of vitamins B1, B6, and B12 (post test).

Results: The mean age of observed patients were $51.58 \pm 12.51$ years. From 117 patients, 73 patients $(62,4 \%)$ were male and 44 patients $(37.6 \%)$ were female. The improvement in overall quality of life in patients was not significant ( $p=0.055)$. Quality of life improvement was only significant in the male group $(\mathrm{p}=0.016)$.

Conclusion: There was no significant difference after 4-weeks-injections of vitamins B Combination to the overall quality of life in chronic kidney disease patients undergoing hemodialysis. But there was found a significant improvement in quality of life in the male patients with chronic kidney disease who had hemodialysis.

Keywords : chronic kidney disease, quality of life, vitamins B1, B6, and B12, SF-8 questionnaire.
\end{abstract}

Article Info: Received 11 Jan 2020; $\quad$ Review Completed 19 Feb 2020; $\quad$ Accepted 27 Feb 2020; $\quad$ Available online 15 March 2020

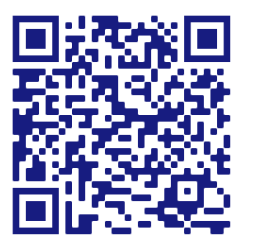

Cite this article as: Pinzon RT, Angela, Changes in Life Quality of Chronic Kidney Disease Patients with Hemodialysis Who Are Given Vitamin B1, B6, and B12 Parenterally, Journal of Drug Delivery and Therapeutics. 2020; 10(2):153-157 http://dx.doi.org/10.22270/jddt.v10i2.3994

*Address for Correspondence: Rizaldy Taslim Pinzon, Department of Neuorology, Duta Wacana Christian University School of Medicine Yogyakarta Indonesia

Dr. Wahidin Sudirohusodo street number 5-25 Yogyakarta 55224, Indonesia

\section{INTRODUCTION}

Chronic kidney disease (CKD) is a disease that causes a progressive decrease in kidney function with diverse etiologies, which can end in kidney failure.[1] To determine changes in quality of life in CKD patients, can be measured using an SF-8 questionnaire developed to replicate SF- 36. In this questionnaire there are several domains that contain perceptions of general health, physical function, limited role due to physical health, pain, vitality, social role functions, mental health and role limitations due to emotional problems. The SF-8 questionnaire has been proven valid in assessing general physical health and mental health in the population. [2]

Assessing the mortality rate in chronic kidney disease patients each year and considering the importance of life quality assessments for evaluating therapy in patients with chronic kidney disease and also to determine the effectiveness of giving a combination of vitamin B (B1, B6, and B12) to the quality of life of CKD patients.

\section{MATERIALS AND METHODS}

The research design used was analytic with quasi experimental methods with one group pre and post test design. Retrieval of data in this study is in the form of SF-8 (Short-Form 8) quality of life questionnaire containing 8 questions whose data was collected at the Hemodialysis unit of Bethesda Hospital and Yogyakarta Panti Rapih Hospital. Vitamin administration is carried out for 1 month as many as eight times parenteral injection, every time the respondent performs hemodialysis (twice a week). Filling out the questionnaire was done twice, namely before being given the first injection of vitamins and after administration of vitamins B1, B6, and B12 (Neurobion Forte 5000mg injection) last time in the fourth week. Furthermore, an analysis of quality of life will be carried out before and after parenteral administration of vitamins B1, B6, and B12.

Ethical approval: Ethical clearance was obtained from Faculty of Medicine Duta Wacana Christian University, Yogyakarta, Indonesia as the institutional ethics clearance comittee (Ethical Clearance 793/C.16/FK/2018). 


\section{RESULTS}

Table 1. Basic characteristics of respondents

\begin{tabular}{|c|c|c|c|}
\hline Characteristics of Respond & & $\mathrm{n}=117$ & $\%$ \\
\hline \multirow[t]{2}{*}{ Sex } & \multirow{2}{*}{$\begin{array}{c}\text { Male } \\
\text { Female }\end{array}$} & 73 & $62,4 \%$ \\
\hline & & 44 & $37,6 \%$ \\
\hline Age, Mean \pm SD & $\begin{array}{l}\text { 51,58 } \pm 12,51 \text { years } \\
\text { Minimum : } 19 \text { years } \\
\text { Maximum: } 82 \text { years }\end{array}$ & & \\
\hline Hemoglobin, Mean \pm SD & $\begin{array}{c}9,22 \pm 1,48 \\
\text { Minimum : 5,5 } \\
\text { Maximum: } 13,20\end{array}$ & & \\
\hline \multirow[t]{9}{*}{ Comorbidities } & $\begin{array}{c}\text { Hypertensive } \\
\text { - Yes } \\
\text { - No }\end{array}$ & $\begin{array}{c}101 \\
16\end{array}$ & $\begin{array}{l}86,3 \% \\
13,7 \%\end{array}$ \\
\hline & $\begin{array}{c}\text { Diabetes Mellitus } \\
\text { - Yes } \\
\text { - No } \\
\end{array}$ & $\begin{array}{l}40 \\
77\end{array}$ & $\begin{array}{l}34,2 \% \\
65,8 \%\end{array}$ \\
\hline & $\begin{array}{c}\text { Cardiovascular } \\
\text { - Yes } \\
\text { - No }\end{array}$ & $\begin{array}{l}31 \\
86\end{array}$ & $\begin{array}{l}26,5 \% \\
73,5 \%\end{array}$ \\
\hline & $\begin{array}{c}\text { Stroke } \\
\text { - Yes } \\
\text { - No } \\
\end{array}$ & $\begin{array}{c}8 \\
109\end{array}$ & $\begin{array}{c}6,8 \% \\
93,2 \%\end{array}$ \\
\hline & $\begin{array}{c}\text { Congenital Kidney } \\
\text { Disease } \\
\text { - Yes } \\
\text { - No }\end{array}$ & $\begin{array}{c}2 \\
115\end{array}$ & $\begin{array}{c}1,7 \% \\
98,3 \%\end{array}$ \\
\hline & $\begin{array}{c}\text { Recurent Kidney Stone } \\
\text { - Yes } \\
\text { - No }\end{array}$ & $\begin{array}{c}9 \\
108\end{array}$ & $\begin{array}{l}7,38 \% \\
92,3 \%\end{array}$ \\
\hline & $\begin{array}{c}\text { Anemia } \\
\text { - Yes } \\
\text { - No }\end{array}$ & $\begin{array}{c}111 \\
6\end{array}$ & $\begin{array}{c}94,87 \% \\
5,13 \%\end{array}$ \\
\hline & $\begin{array}{c}\text { Hiperkolestrolemia } \\
\text { - Yes } \\
\text { - No } \\
\end{array}$ & $\begin{array}{c}4 \\
113\end{array}$ & $\begin{array}{c}3,4 \% \\
96,6 \%\end{array}$ \\
\hline & $\begin{array}{c}\text { Kidney Infection } \\
\text { - Yes } \\
\text { - No }\end{array}$ & $\begin{array}{c}5 \\
112\end{array}$ & $\begin{array}{c}4,3 \% \\
95,7 \%\end{array}$ \\
\hline \multirow[t]{7}{*}{ Comedication } & $\begin{array}{c}\text { Folid Acid } \\
\text { - Yes } \\
\text { - No }\end{array}$ & $\begin{array}{c}102 \\
15\end{array}$ & $\begin{array}{l}87,2 \% \\
12,8 \%\end{array}$ \\
\hline & $\begin{array}{c}\text { Calcium Carbonat } \\
\text { - Yes } \\
\text { - No }\end{array}$ & $\begin{array}{l}82 \\
35\end{array}$ & $\begin{array}{l}70,1 \% \\
29,9 \%\end{array}$ \\
\hline & $\begin{array}{c}\text { Antihypertensive drugs } \\
\text { - Yes } \\
- \text { No }\end{array}$ & $\begin{array}{l}96 \\
21\end{array}$ & $\begin{array}{l}82,1 \% \\
17,9 \%\end{array}$ \\
\hline & $\begin{array}{c}\text { Antidiabetic drugs } \\
\text { - Yes } \\
\text { - No }\end{array}$ & $\begin{array}{l}27 \\
90\end{array}$ & $\begin{array}{l}23,1 \% \\
76,9 \%\end{array}$ \\
\hline & $\begin{array}{c}\text { Anti platelet } \\
\text { - Yes } \\
\text { - No }\end{array}$ & $\begin{array}{c}11 \\
106\end{array}$ & $\begin{array}{c}9,4 \% \\
90,6 \%\end{array}$ \\
\hline & $\begin{array}{c}\text { Lipid lowering drug } \\
\text { - Yes } \\
\text { - No }\end{array}$ & $\begin{array}{c}6 \\
111\end{array}$ & $\begin{array}{c}5,1 \% \\
94,9 \%\end{array}$ \\
\hline & $\begin{array}{c}\text { Hematopoetic agent } \\
\text { - Yes } \\
\text { - No }\end{array}$ & $\begin{array}{l}97 \\
20\end{array}$ & $\begin{array}{l}82,9 \% \\
17,1 \%\end{array}$ \\
\hline Comorbidities & $\begin{array}{l}<2 \text { Comorbidities } \\
\geq 2 \text { Comorbidities }\end{array}$ & $\begin{array}{c}11 \\
106\end{array}$ & $\begin{array}{c}9,4 \% \\
90,6 \%\end{array}$ \\
\hline
\end{tabular}


Table 2. Quality of life scores (SF-8 score) in the pre and post test

\begin{tabular}{|c|c|c|c|}
\hline Variabel & Pre test & Post Test & p-value \\
& & Median & \\
\hline SF-8 Total Score & 21,00 & 20,00 & 0,055 \\
\hline SF-8 Physical Score & 14,00 & 13,00 & 0,138 \\
\hline SF-8 Mental Score & 7,00 & 6,00 & 0,071 \\
\hline
\end{tabular}

*Non-Parametric - Wilcoxon

The data used in this study is still in a scale 8 (minimum) 42 (maximum) based on the scoring of the questionnaire. At the first visit before receiving the vitamin (pre-test), the median total quality of life score (physical + mental) was 21,00 . Then when filling out the questionnaire after the respondents were given vitamins, there was a decrease in the average SF- 8 total score to 20,00 . The smaller the SF-8 score obtained can indicate that the quality of life is getting better, and the greater the score obtained, the worse the quality of life.

The questionnaire used in this study was an SF-8 questionnaire containing 8 questions. Questions number 1-5 are questions with a physical domain and questions number 6-8 are questions with a mental domain. In assessing the physical quality of life score (SF-8 physical) at the first visit and subsequent visit, there was a decrease in the median physical SF-8 score from 14,00 to 13,00 . In assessing the mental quality of life score at the first visit and subsequent visit, there was also a decrease in the median mental SF-8 score from 7,00 to 6,00. Can be seen in the table of p-value values from pre and post test ( $\mathrm{p}$-value> 0.05), it can be concluded that there were no significant changes in the results of pre and post administration of vitamins B1, B6, and B12. The analysis used to determine changes in quality of life in this study was paired t-test, but in the total score, physical score and mental score did not meet the normality requirements of the data, so that non-parametric Wilcoxon analysis was carried out.

Table 3. Analysis of SF-8 questions aspects between before and after administration of parenteral vitamins B1, B6, and B12

\begin{tabular}{|c|c|c|c|}
\hline \multirow{2}{*}{ Variabel } & \multicolumn{2}{|c|}{ Pre-Test } & Post-Test \\
\cline { 2 - 3 } & \multicolumn{2}{|c|}{ Median } & \\
\hline General Health Perception & 3,00 & 3,00 & 0,455 \\
\hline Physical Functioning & 3,00 & 3,00 & 0,071 \\
\hline Physical Role Functioning & 2,00 & 2,00 & 0,425 \\
\hline Bodily Pain & 3,00 & 3,00 & 0,267 \\
\hline Vitalitity & 2,00 & 2,00 & 0,736 \\
\hline Social Functioning & 3,00 & 3,00 & 0,474 \\
\hline Mental Health & 2,00 & 2,00 & 0,041 \\
\hline Mental Role Functioning & 2,00 & 2,00 & 0,145 \\
\hline
\end{tabular}

${ }^{*}$ Non-Parametric - Wilcoxon

Based on the results of the analysis of aspects of the questions from the SF-8 questionnaire consisting of 8 questions, presented in Table. 3 . In the SF-8 question analysis Bonferroni correction was performed, so that the $\mathrm{p}$-value limit value was 0.006 ( $\mathrm{p}$-value 0.05 divided by $8=$ 0.006). It can be concluded that there was no significant difference between the results of pre and post administration of vitamins B1, B6, and B12 (p-value> 0.006). The data used in the analysis of the SF-8 aspect is still on a scale of 8-42 (minimum score $=8$ and maximum score $=42$ ), so that the higher median of the score, it means the worse quality of life.

Table 4. Quality of life based on age group, gender and comorbidites

\begin{tabular}{|c|c|c|c|}
\hline \multirow[t]{2}{*}{ Variabel } & $\begin{array}{c}\text { SF } 8 \text { total } \\
\text { Pre-Test }\end{array}$ & $\begin{array}{l}\text { SF } 8 \text { total } \\
\text { Post-Test }\end{array}$ & p-value \\
\hline & \multicolumn{3}{|c|}{ Mean \pm SD } \\
\hline \multicolumn{4}{|l|}{ Age a } \\
\hline$<56$ years & $20,20 \pm 5,10$ & $19,26 \pm 5,38$ & 0,187 \\
\hline \multirow[t]{2}{*}{$\geq 56$ years } & $20,15 \pm 4,46$ & $19,27 \pm 4,23$ & 0,200 \\
\hline & \multicolumn{3}{|c|}{ Median } \\
\hline Male b & 21,00 & 19,00 & $0,016 *$ \\
\hline Female b & 20,50 & 21,00 & 0,959 \\
\hline Comorbidities $<2$ b & 19,00 & 19,00 & 0,645 \\
\hline Comorbidities $\geq 2 \mathrm{~b}$ & 21,00 & 20,00 & 0,063 \\
\hline
\end{tabular}

a. Paired t- test b. Non-Parametric - Wilcoxon 
The existence of a relationship that was statistically significant in sex in the male group ( $\mathrm{p}$-value $=0.016$ ) as a confounding variable on total quality of life ( $p$-value $<0.05$ ). While other confounding variables such as age, female sex, comorbidities $<2$ and comorbidities $\geq 2$ there was no significant relationship with the quality of life of the total subjects (total SF-8) (p-value> 0.05). In the analysis sub-group table for the age group analysis was carried out with paired t-test, whereas in the sex and comorbid groups an analysis was performed with the Wilcoxon non-parametric test because it did not meet the data normality requirements.

\section{DISCUSSION}

In this study, the characteristics of respondents undergoing hemodialysis from the two hospitals namely Bethesda Hospital and Yogyakarta Panti Rapih Hospital were mostly male, as many as 73 people (62.4\%) compared to female sexes, as many as 44 people $(37,6 \%)$ of the total respondents, 117 people. The results of the same study can be found in the previous study at Bethesda Hospital in Yogyakarta who received 47 people $(62.7 \%)$ who were undergoing hemodialysis with male sex and 28 people (37.3\%) female sex .[3] This is also the same in a other study of 320 respondents found 183 people (57.2\%) were male and 137 people (42.8\%) were female.[4] The prevalence of chronic kidney disease is more prevalent among male than female.[4]

The mean age of the subjects in this study was $51.58+12.51$ years. This is similar to the study that the average age of patients undergoing hemodialysis was $52.5 \pm 15.9$ years. [5] The average value of hemoglobin in this study was $9,228 \pm$ 1,488 , this is similar to the previous research which is $9.4 \pm$ 1.7.10.[6] The value of hemoglobin in this study was found to be below the normal value so that the results of the study it was found that 111 of 117 patients had anemia. Anemia occurs when there is a hypoxic response due to a reduction in the functional renal parenchyma so that erythropoietin deficiency is produced by peritubular cells. In patients with chronic kidney disease, the body is not able to stimulate peritubular fibroblasts in the kidneys to increase EPO (erythropoetin) production so that anemia develops. The other factors that cause anemia are iron deficiency, vitamin deficiency, decreased life span of erythrocytes that experience hemolysis due to bleeding, and hemodialysis plays a role in the process of anemia in patients with chronic kidney disease because most red blood cells will be damaged during the hemodialysis process.[7]

Summary of the total SF-8 score, PCS (Physical Component Score), and MCS (Mental Component Score), in this study there was no significant change in the post given combination of B vitamins as much as eight times per hemodialysis for 4 weeks ( $p$-value >0.005). Previous research examined the effectiveness of combination vitamin $\mathrm{B}$ (B1, B6, and B12) on improving the quality of life in hepatitis patients.[8] Results of the study in the fourth week have not found significant changes in quality of life. After 24 weeks there was a significant improvement in quality of life, the patient's PCS score was $>30$ (average) and the patient's MCS score was $>50$ (normal) and in the $48^{\text {th }}$ week all PCS scores and MCS patients there were more patients who scored 50 or more as measured by the SF-36 questionnaire. This shows a significant increase in physical and mental quality of life in patients with chronic disease after giving vitamins for 24 weeks - 48 weeks. ${ }^{[8]}$ Based on that research, it can be concluded that it takes longer time to administer vitamins at This study looks at the effectiveness of combination B vitamins for a significant improvement in quality of life in patients with chronic kidney disease undergoing hemodialysis.

From the analysis that has been done can be seen in Table. 3 regarding the analysis of aspects of SF-8 questions on 117 respondents. After the Wilcoxon non parametric test was carried out due to abnormal data distribution There were changes in the eight aspects of the SF-8 question in the form of increasing scores, but the results were not statistically significant based on Bonferroni's correction ( $p>0.006)$. This is similar to other research regarding the effectiveness of giving vitamin B12 to hemodialysis patients. Obtained a significant improvement in the quality of life of post treatment (vitamin B12) only on the aspect of social function $(p=0.047)$ after the combination of vitamin B for 3 months. This can be caused by a lack of long research time to observe the effectiveness of vitamin B in improving quality of life.[9]

In this study, the most widely used comedication by patients was folic acid, which was obtained in 102 (87.2\%) hemodialysis patients. Previous research has shown that folate deficiency is associated with depression because folate plays an important role in the process of methylation and synthesis of neurotransmitters in the central nervous system.[10] Increased homocysteine levels (hyperhomocysteinemia), is a sign of folate deficiency and vitamin B12 deficiency, which can eventually causing oxidative stress, resulting in cerebral brain damage, neurological damage and neurotransmitter deficiency.[11] In this study, most research subjects had received folic acid in order to avoid folate deficiency. Folic deficiency is associated with the occurrence of depression and cognitive decline in patients, while low vitamin B12 concentrations are mainly associated with cognitive impairment. The combination of folic acid and vitamin B combination plays an important role to increase the summary score of the mental components of hemodialysis patients to prevent folate and vitamin B12 deficiency.[12]

In this study, the relationship between the factors that influence total quality of life (SF-8 Total) was measured in patients undergoing hemodialysis. Subgroup analysis could show a significant change in the male group with a value of $p$ $<0.05(\mathrm{p}=0.016)$ which showed that there was a significant increase in quality of life after administration of vitamins B1, B6, and B12 in the male group research subjects. In the female group no significant changes were found $(p=0.959)$ and the median quality of life pre and post vitamin administration was increase and this showed that female had a worse quality of life than male. The results of the study in the female's group can be influenced by the small number of female patients and the uneven distribution of female's data.

In this study there were age groups $<56$ years and $\geq 56$ years, but no significant changes were found in the 2 age groups. In comorbidities, there were 2 groups, namely groups of patients with comorbidities $<2$ and patients with comorbidities $\geq 2$ and no significant results $(p>0.05$ ). Comorbidity is another condition besides chronic kidney disease which consequently can affect other organs. This condition can also be a factor that causes chronic kidney disease, such conditions as hypertension and diabetes.[12] Most patients in this study suffered from hypertension, followed by diabetes, cardiovascular disease. As many as $94.87 \%$ of patients have anemia and $90.6 \%$ have more than two comorbidities. The presence of other chronic diseases as comorbidities greatly influences the quality of life of patients with chronic kidney disease undergoing hemodialysis, therefore it is very important to treat treatment for comorbidity because it can help improve the quality of life of 
patients with chronic kidney disease who experience hemodialysis.[12]

The limitation of this study was that this study was carried out for 4 weeks, therefore changes and improvement in quality of life after administration of vitamins B1, B6, and B12 had not occurred significantly. This study also did not have a treatment control group (not given vitamins), so it could not measure and compare the quality of life in patients with chronic kidney disease who received vitamin B1, B6, and B12 therapy with the control group (not given vitamins).

\section{Conflict of interest}

All authors declare that they have no conflict of interest.

\section{Funding}

There was no funding received for this study.

\section{REFERENCES}

1. Suwitra, K. Chronic Kidney Disease. In: Setiati S, Alwi I, Sudoyo AW, Simadibrata M, Setiyohadi B, Syam AF, editors. Internal Medicine Book. $6^{\text {th }}$ ed. Jakarta : Interna Publishing; 2014.

2. Roberts B, Browne J, et al. (2008) The Reability and Validity of The SF-8 With A Conflict-Affected Population in Northern Uganda. Health and QOL Outcomes; 2008. Available from :

https://www.ncbi.nlm.nih.gov/pubmed/19055716

3. Linda, Ni Putu. Characteristics Quality of Life in Patients with Chronic Kidney Disease Undegoing Hemodialysis in Bethesda Hospital Yogyakarta. Yogyakarta : Faculty of Medicine Duta Wacana Christian University; 2017.

4. Gerasimoula, K., Lefkothea, L., Maria, L., Victoria, A., Paraskevi, T., \& Maria, P. Quality of Life in Hemodialysis Patients. Materia socio-medica; 2015; 27(5):305-9. Available from: https://www.ncbi.nlm.nih.gov/pubmed/26622195

5. Cruz, M.C., Andrade, C., Urrutia, M.I., Draibe, S., et al. Quality Of Life in Patients with Chronic Kidney Disease; 2011; 66(6):991-995.
Available from :

https://www.ncbi.nlm.nih.gov/pmc/articles/PMC3130152/

6. Tsai YC HC, et al. Quality of Life Predicts Risks of End-Stage Renal Disease and Mortality in Patients with Chronic Kidney Disease. Nephrol Dial Transplant; 2010. Available from: https://www.ncbi.nlm.nih.gov/pubmed/20037172

7. Sukandar, E. Nephrology Clinic. Edisi IV. Bandung: IPEDE; 2013.

8. Ashous, Nermeen, et al. Folic Acid and Vitamin B Complex Improves Quality of Life in Hepatitis C Infected Patients Treated with Peginterferon and Ribavirin. British Journal of Medical and Health Research; 2015. Available from :

https://www.researchgate.net/publication/273551099_Folic_Acid_ and_Vitamin_B_Complex_Improves_Quality_of_Life_in_Hepatitis_C_In fected_Patients_Treated_with_Peginterferon_and_Ribavirin/downlo ad

9. Saifan, C., Samarneh, M., Shtaynberg, N., Nasr, R., El-Charabaty, E., El Sayegh,S. Treatment of confirmed B12 deficiency in hemodialysis patients improves Epogen $₫$ requirements. International journal of nephrology and renovascular disease; 2013; 89-93. Available from: https://www.ncbi.nlm.nih.gov/pmc/articles/PMC3681404/

10. Miller, A.L. The Methylation, Neurotransmitter, and Antioxidant Connections Between Folate and Depression. Altern Med Rev. 2008; 13; 216-226. Available from: http://archive.foundationalmedicinereview.com/publications/13/3 /216.pdf

11. Reynolds, E. Benefits and Risks of Folic Acid to the Nervous System. J Neurol Neurosurgery Psychiatry; 2002; 72(5):567-571. Available from: https://www.ncbi.nlm.nih.gov/pmc/articles/PMC1737896/

12. Braga, S.F., Peixoto, S.V., Gomes, I.C., Acurcio, F.A., Andrade, E.I., Cherchiglia, M.L. Factors Associated with Health-Related Quality of Life in Elderly Patients on Hemodialysis. Rev Saude Publica; 2011; 45(6):1127-36. Available from: https://www.ncbi.nlm.nih.gov/pubmed/22124742 